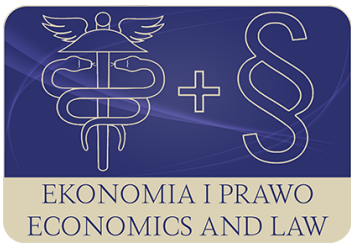

EKONOMIA I PRAWO. ECONOMICS AND LAW

Volume 17, Issue 1, March 2018

p-ISSN 1898-2255, e-ISSN 2392-1625

www.economicsandlaw.pl

EKONOMIA I PRAWO
ECONOMICS AND LAW

ORIGINAL ARTICLE

received 13.06.2017; revised 13.03.2018; accepted 31.03.2018

Citation: Deszczyński, B. (2018). The integrated relationship management framework. Ekonomia i

Prawo. Ecomomics and Law, 17(1): 17-31. doi:10.12775/EiP.2018.002.

\title{
The integrated relationship management framework
}

\section{BARTOSZ DESZCZYŃSKI}

Poznan University of Economics and Business, Faculty of International Business and Economics, Department of International Marketing, al. Niepodległości 10, 61-875 Poznań, Poland

$\square$ bartosz.deszczynski@ue.poznan.pl

\begin{abstract}
Motivation: Relationship management (RM) has been capturing the interest of scholars and practitioners since this term was first brought to light by L. L. Berry and T. Levitt in 1983. Numerous publications and billion-dollar software industry validate its vitality, but plethora of relationship oriented practices and isolated models spread it to thin. Therefore there is a need to synthesize the existing body of knowledge.

Aim: This article presents discussion on conventional RM theory merging it with the other complementary concepts: resource based view (RBV), human resources management

(HRM), knowledge management (KM), customer relationship management (CRM), corporate social responsibility (CSR). Its main aim is to discuss the integrated relationship management framework — a step towards a RM grand theory.

Results: The main contribution of this paper is the adumbration of relationship management integrated framework, which links the maturity of corporate RM with proficiency in three interrelated dimensions: strategy / business model, the information technology and organizational change management.
\end{abstract}

Keywords: customer relationship management (CRM); relationship assets; relationship capital; relationship management; resource based view $(R B V)$

JEL: L230; L250

\section{Introduction}

Since more than two decades, the term 'relationships' occupies prominent position in management sciences. The relationship concept as an important alternative to transactional style of doing business was defined and reinvented for 
the whole bunch of areas and fields of research, including industrial marketing, services marketing, strategic management, customer relationship management (CRM) - to name only a few. This diversity indicates that the relationship management (RM) has a good potential for a fruitful scientific discourse, yet simultaneously it still lacks a more complex and generalized theory (Gummesson, 2017a, pp. 16-19).

The promise of satisfied, loyal and profitable customers has also captured the minds of the business practitioners. However, according to series of research studies - up to $70 \%$ of the companies assess their customer relationship management programs as a failure (Deszczyński \& Fonfara, 2014).

Although the logic and reasoning of relationship approach seems to be correct, it is blurred in diverging business practices and theoretical perspectives. Hence the article synthesizes the mainstream of contemporary body of research on RM and attempts to establish links between the RM and other complementary concepts which base on the premise of relationship assets: resource based view (RBV), human resources management (HRM), knowledge management $(\mathrm{KM}), \mathrm{CRM}$ and corporate social responsibility (CSR). As a result the new broader scope of RM is outlined.

\section{Relationship management and the relationship assets concept - theoretical background}

In the subject literature the RM is perceived as a bundle of strategies and methods devoted to strengthening the loyalty (e.g. of a customer or partner) and reducing operating costs of sales, promotion and acquisition (Otto, 2004, pp. 189-197; Reichheld \& Markey, 2012), organizational philosophy oriented on value creation (Piercy, 2003), managerial process aimed at meeting shareholders' goals by reinforcing relations with selected customers and partners (Doyle, 2003). These characteristics enable to clearly distinguish it from functional and operational marketing strategies and to interpret it in the light of strategic management (Mitręga et al., 2012, pp. 739-751; Tvede \& Ohnemus, 2001). Thus customer or partner relationship management is situated as part of incremental strategic management and should be interlinked with global strategy (Deszczyński, 2016a, pp. 73-104; Mitręga, 2015, pp. 139-147).

The core characteristics of relationship business model are: long-term perspective, reciprocity of internal and external relations, partner dialogue and orientation on value creation process (Galbreath \& Rogers, 1999, pp. 161-171; Injazz \& Popovich, 2003, pp. 672-688). For companies pursuing this concept, the source of competitive advantage are relationships with the customers, which in turn are fuelled by the knowledge of customer needs gained by committed employees and partners (Otto, 2001) and proper use of information and communication technologies (ICT) (Stachowicz-Stanusch \& Stanusch, 2007). Hence relationships can be viewed as strategic assets falling within J.B. Barney's (1991) 
VRIN model (Valuable, Rare, Inimitable, Non-substitutable and RM as a distinguishing interpretation of RBV.

The nature of relationship assets implies that they are created in the process of communication and that their existence can be identified by the creation of knowledge with an economic utility value. Moreover the relationship assets emerge as an accumulated sum of experiences, trust, commitment and mutual learning processes developed during longer period of time (Doney \& Cannon, 1997, pp. 35-51; Szymura-Tyc, 2004, pp. 207-213; Zdziarski, 2016, pp. 657668). Thus they can be defined as intangible resources, an effect of a process of continuous interactions creating useful knowledge and leading to development of positive associations with the organization, its brands and representatives, what in turn brings benefits for particular individuals and reinforcement of competitive position of the company itself (Deszczyński, 2014, pp. 25-44).

\section{Methods of research}

This article offers a discourse based on comparative review of contemporary developments in the field of relationship management and theoretical synthesis of selected relationship management models. These two main methods are supplemented with personal reflection based on author's ongoing research and contact with business people (compare e.g. Deszczyński (2013, pp. 24-32; 2016b, pp. 280-288); Deszczyński et al. (2017, pp. 91-109)).

The body of scientific work on RM is huge. Google Scholar found approx. 66.000 publications directly referring to RM in the last ten years. Therefore it is impossible and does not make sense to review all of them. Instead, this article presents a comparative analysis of models or mature concepts of internationally recognized authors who have won their names thanks to many years of research on relationship management or relationship marketing. In this article both terms are treated as marketing-oriented management, as the relationship between marketing and other disciplines of management is only a matter of perspective (Gummesson, 1999, p. 75). The term relationship marketing is therefore applied predominately to reflect original work of a given author, while relationship management works as a basic term. In addition the article compiles representative set of commercial customer relationship frameworks developed by international consultancies. These models were selected upon criteria of long-term and widespread application as well as their recognition by the RM theorists.

Both theoretical and practical models are discussed and synthesized to create a common ground for further supplementation with author's reflections on complementary relationship based concepts. The final discussion addresses the complexity of RM in a proposition of an integrated framework. 


\section{Results and discussion - the relationship management models}

In their CRM strategy framework A. Payne and P. Frow (2013, p. 205) identify key processes which are responsible for development of customer relationship business model, its organizational implementation and technical support. They link the overall success of organization with the incorporation of core characteristics and objectives of relationship marketing to the global strategy development process. This involves inspiring the mission and vision statements with the relationship spirit, but also definition of key groups of customers and other important stakeholders, like suppliers of strategic goods/technologies and key distribution partners.

The value creation process should define how to maximize the lifetime value of desirable customer segments reflected both in benefits for the customers and the company. The best way to achieve this goal the authors propose is the shift from making, selling and servicing to listening, customizing and co-creating. The co-creation experience is facilitated by integration of multi-channel communications exposing opportunities for customer - brand/ company encounter on cognitive, emotional and behavioral levels. This requires seamless cross-functional integration assisted by ICT, which should deliver exceptional satisfaction, because only superior customer experience can guarantee the loyalty effect occurs (Jones \& Sasser, 1995).

The information management process should enable to build-in a 'corner-shop principle' into a practice of every organization, by implementing $360^{\circ}$ customer view concept and creating working memory of a customer. This process starts and ends in two-way dialogue between the customer and the company represented by diverse actors assisted by front- and back-office applications linked to one central data repository.

Finally the performance assessment process delivers KPIs showing the rate of progress in customer RM. Unlike the traditional approach to business metrics, the financial performance is understood as the end-effect, but not an ultimate goal of a company. Just like in the W.E. Sasser et al. (1997), the right sequence starts in open and inspiring behavior of the leaders and the management of the organization, followed by an active engagement of the employees and finally the satisfaction of the customers. Therefore business performance has to be reflected in customer, employee, shareholder value, as well in cost reduction (Payne \& Frow, 2013; Peck et al., 2013).

I.H. Gordon (2013, pp. 57-105), in his CREVITS model addresses seven important issues in RM planning (customer selection, relationship objectives, engagement, value, innovation, teaching, sharing). It starts with the application of $360^{\circ}$ customer view concept by connecting all relevant actors with direct access to customers and analysis of customer generated data (e.g. social media activities). This data enables to categorize customers upon their needs, financial profitability (including cost-to-serve) but also assess their potential and social 
impact (e.g. share of customer, engagement). The subsequent customer alignment process maps the needs of selected group of customers to organizational capabilities. The development of excellence in respect of these capabilities should provide the customers with superior value proposition.

Relationship objectives involve the development of behavioral customer segmentation and targets related to the advancement of customers in the relationship ladder. The specific-customer value is facilitated thanks to customer sensing as a company response to a joint process of collaborative innovation (Szymura-Tyc, 2003, pp. 17-32) and co-created in S-D logic manner (Vargo \& Lutsch, 2016, pp. 1-10). I.H. Gordon (2013) implies that the profit generation process is directly affected by the ability of the company to assist the customer in extraction of individually relevant elements of potential value hidden behind its products and services. This requires unbundling of these elements as compatible blocks, which can be matched by the customer with help of company representatives.

For E. Gummesson (2008; 2017a, pp. 16-19) marketing is about managing relationships, networks and integration. In this context the role of a company is to offer an attractive value proposition. In co-creation with the customers and a network of contributors the proposition is actualized into service. Like other representatives of the Nordic School, he sees the market encounter in network lenses, therefore instead on concentrating on dyadic relationships, he advocates the many-to-many marketing or total relationship marketing (TRM).

In his book he identifies 30 forms of relationships: mega- (e.g. personal and social networks), special (e.g. e-relationship) and nano- (e.g. relationships between operations management and marketing) (Gummesson, 2017b). Referring to the services marketing principle E. Gummesson states that marketing is performed by everyone, not just by the personnel of marketing department. Moreover, the traditional idea of a company limits the perception of relationships, which occur in a reality of complex 'imaginary' organizations, beyond the control of a single entity.

This does not mean the relationships are an abstract phenomenon. However the economies of relationships can turn into scalable profit only for those companies, which convert the intellectual capital (especially knowledge and relationships) into financial capital by adopting a good mix of short- and long-term goals and support these choices with investment in people (seen as the primary enabler of the organization), processes and technology (Gummesson, 2014, pp. 656-662).

Another big name in RM representing the Nordic School is Ch. Grönross. In his research he focuses on the role of the customer in value creating process and envisages the proper respond of the company to take advantage of value co-creation. Grönross calls a traditional approach a closed system. If the provider has no or very limited contact with the end-user, he cannot influence the individual value creation process and his role comes down to mere value facilitator. In an open system, where the use of service activities and of goods 
embedded in a service system gives a space for active collaboration with the customer, the company advances to a position of value co-creator (Grönroos, 2011, pp. 279-301; Grönroos \& Strandvik, 2008).

The value co-creation challenges the company in terms of adaptability, flexibility and requires intensified interactions. Grönroos's (2007) vision of such a system is embodied in his CSS model (conceptualizing - systematizing servicizing), which describes the way how to use service inherent advantages for the valuable offer creation. Conceptualizing is the process of development of value proposition, which involves designing the platform for interactions with the customers before and after the transaction is concluded. Systematizing is determining what resources and processes are needed to support customer's activities in a mutually value generating way and making them available to the customer. Servicizing is the actual interaction with the customer which creates real value-in-use.

D. Peppers and M. Rogers are business consultants, who have gave CRM an alternative name - one-to-one marketing (Peppers et al., 1999). Simultaneously they have developed a framework for CRM deployment called IDIC. IDIC has been frequently mentioned in the literature - a privilege of being one of the first of its breed (Buttle, 2009; Srivastava, 2013, pp. 16-25). Its four components: identify, differentiate, interact, customize make this model easy to comprehend, while not oversimplifying the relationship concept (Peppers \& Rogers, 2004).

The focal point in IDIC model is laid on learning and customization. In the initial acquisition phase of the relationship, a company has to locate and directly contact a fair number of customers by creating as much room for interaction as possible. Every contact regardless of channel and context should be seen as a learning opportunity enabling effective differentiation. The continuing focus on learning is also reflected in the third process of interactions. The crucial point here is to guarantee an undisrupted dialogue to 'pick up, where the last one left off' (Peppers et al., 1999). Finally customization process builds on cumulative information on customers enabling the company to propose tailored offers based on customization of some aspects of service or product (Peppers \& Rogers, 2011).

A much more detailed approach is offered by QCi's Customer Management Assessment Tool model (CMAT). CMAT is probably the most comprehensive CRM analytical tool applied on a large scale (since 1993 more than 600 entities have run through CMAT procedure) (CM FrameWorks, 2017). The 260 questions, which build-up the model questionnaire are distributed through several areas of interest: analysis and planning, proposition, customer management activities, people, measurement, customer experience, information and technology (Starkey et al., 2002, pp. 378-385).

The analysis and planning starts with behavioral customer base definition to be concluded in detailed plans for acquisition, penetration and retention of selected customer segments. The development of a proposition has to involve 
all the departments that impact customer experience with the performance indicator for every key aspect of service. Customer management activities include inter alia: targeting, handling of enquiries and support for new and upgrading customers.

CMAT directly links the performance of customer management activities with the support from the leadership structure and enablement of own people. Hence, it includes identification and development of needed competencies and understandable objectives linked to the overall business goals and employee satisfaction. This area also covers the supplier relationship management, which includes the development of proper strategies to source, inform and select suppliers as well as to decide on strategic alliances (Wagner \& Johnson, 2004, pp. 717-730).

\section{The synthesis of relationship management models}

The analysis of presented models reveals several key issues, which have to be considered when discussing the maturity of RM. The CREVITS model requires that the organization aligns its customer-centric strategy and processes, leadership concentrated on organic growth of relationship assets, effective culture of fairness towards the customers, employees and other stakeholders, flexible structure, portfolio of skilled and engaged people as well as modern technologies. The A. Payne's and P. Frow's CRM framework integrates RM and CRM highlighting the need for multiple stakeholder management. It implements S-D logic of value co-creation linking it tightly with the multi-channel communications and expressing the need for relationship performance indicators. The concept of TRM highlights the core nature of relationship domain, which are interactions of human beings. The work of Ch. Grönross is clearly inspired by the principles of service industry with an active role of the customers and employees. The lifeline of a company is therefore its communication system, which supports internal marketing and opens the company towards its customers. The four parts of IDIC framework overlap on the premise of systematic customer knowledge management. CMAT model supports the holistic understanding of RM and clearly indicates that in general, the roots of sustainable performance are in between of customer and employee interaction.

It seems that an undisputable basis for proficiency in RM is to know the customers really well, to share this information throughout the organization and to use it to increase the value that benefits both the company and its customers. This goal can be achieved through multi-channel interactions, advanced customer segmentation and customization. Although calling particular processes differently or aggregating them in a specific way, all of evoked models adopt process approach to management. They also take the multi-stakeholder perspective with emphasis laid on employees and business network (with exception of IDIC). 
What distinguishes theoretical models from commercial tools is their interest in applying $\mathrm{S}-\mathrm{D}$ logic to customer value creation and relatively high attention to strategic framework of the company. This includes the alignment of global and relationship strategy and corporate culture.

It seems an integrated RM framework should address strategic and change management dimension of the business practice with ICT as a third technological dimension, an enabler of communication and knowledge processes. The strategic dimension can be associated with an overall idea how to serve the customers, where does the value they expect migrate and how to align own resources to develop and update capabilities to keep pace with these trends. The change management dimension is about assuring that the organization (with people and processes on top) is ready to deploy this general idea in a day-to-day work. Nonetheless the evoked models touch rather superficially the internal, non-direct customer issues without establishing significant links to RBV, HRM, $\mathrm{KM}$ and CSR. Likewise they describe the use of modern technologies as an obviousness and as secondary factor to company success without much reflection on ICT governance, so how to implement information and communication systems to achieve business goals.

Scheme 1 depicts the complete set of RM dimensions. The solid line marked elements directly originate in the models presented in the previous section. The dotted line marked elements are suggested to supplement the framework. All three RM dimensions are interdependent, although one can assume that in a particular situation they will not be equally important. E.g. micro- or small enterprises could potentially reach the same results of data management with simple ICT tools, while the bigger organizations (in terms of number of customers, processes, employees and specialized organizational units) have to compensate for their size with advanced tools and strategies.

The fundamental assumption in terms of the customer strategy shared in the presented model is the S-D logic. The servitization of the offer and the acknowledgement of the role of the customers in value creation finally mark the new era of human empowerment in the economy. Both customers and employees need this to create substantial individually significant value, which is beneficial for themselves and for value proposing business entity.

The proposed framework develops an endogenous perspective in strategic management, which is preparing organization for change rather than planning far-reaching market scenarios. Such approach is characteristic for RBV, which links competitive advantage with proper choice and development of assets, their effective use by improvement of strategic skills and their configuration into core competencies (Hamel, 2002). Hence knowledge is a resource of strategic importance (Hamel \& Prahalad, 1999) and care for 'knowledge worker' is one of strategic domains of business activity (Drucker, 2010).

In consequence in mature relationship-driven company HRM activities should be redefined. The most important goal is the identification of key groups of employees characterized by possession of VRIN skills or extraordinary com- 
mitment. As workforce portfolio management is not about sheer steering, the employees have to be empowered. The basic pillars of empowerment include: distribution of high quality information, authority to make most of decisions autonomously, encouragement to innovate, shift in managerial activities from detailed work distribution and control towards strategic planning and leadership (Smith, 2006).

One of crucial effects of employee empowerment should be their engagement and in turn the engagement of their customers. Hence, the engagement metrics should supplement other relationship KPIs like satisfaction, customer loyalty/employee attrition rate and customer profitability/employee work efficiency. All of them indicate current health of the organization and its perspectives for the future.

The common element that links internal and external RM is knowledge created in the process of communication (Mitręga, 2012, pp. 486-496). Knowledge creation is not a traditional input-output sequenced process but forms a spiral moving, which goes through interrelated organizational units accompanying other processes with more specified problem-solving objectives (Nonaka \& Peltokorpi, 2006, pp. 73-82). The main task here is to create an organizational background for knowledge transfer into corporate assets. It can be done by creation of positive environment and procedures for ex-/internalization of tacit knowledge and codification of explicit knowledge.

The conversion of information into data and data into knowledge requires storing, searching and retrieving of knowledge, but also supporting communication (Deng, 2010, pp. 49-61). Collaborative ICT infrastructure should be applied in interactions with internal stakeholders, where it can take form of file sharing or online project management. It is however unlikely to get the same level of mutual trust and engagement with wider groups of external stakeholders, which should be rather consulted or informed. The goal of informing customers and business partners can be mastered via traditional web services (e.g. newsletters) and social media. The so called social-CRM can play a significant role as a platform for engaging potential and existing customers and business partners who may eventually come into closer relations with the company. For many businesses, like FMCG-companies, social media can be the only way to connect to their end-customers. In contractual B2C industries and in B2B sector the integration of social profiles with conventional databases can deliver behavioral insights improving the level of intimacy of the relationships.

Customer-centric processes are the backbone of the day-by-day performance. The three most commonly referred processes: customer selection, multi-channel communication and mutual learning have to be supplemented by other explicitly named processes like: lead management, cross-/up-selling, loyalty management and anti-churn management. Moreover, all customer value affecting processes have to be tested on their customer-centricity and updated on regular basis as a direct representation of the company's ability to maintain homeostasis. 
The openness for dialogue, transparency and collaboration are foundations of so called high-performance work systems (Amann \& Stachowicz-Stanusch, 2013). The core idea behind these systems is an extraordinary employee commitment thanks to their needs' fulfillment all across the Maslow pyramid. Correspondingly one of the factors that distinguishes companies advanced in RM is the strategic approach of CSR and its primarily application as an internal engagement support tool and not a PR tool. Hence, it requires lifting command \& control culture as CSR is not effective by the point company starts to assess its employees and other stakeholders as partners. Supportive, flexible corporate culture will bring such values and behavior patterns as: care for the interest of the customers, fellow employees, owners and partners, appreciation of human beings, willingness for change and process-orientation (Kotter \& Heskett, 1992). The high-performance work systems improve customer loyalty, employee motivation and investor attraction (O'Riordan et al., 2015).

Finally the strategic and organizational performance in RM brings the development of relationship assets. This truly unique and temporary capital can be effectively used in competition for the best customers, employees and network of supporting partners. The meta-process of organizational homeostasis integrated in RM business model will also provide for the organizational resilience and a long-term competitive advantage.

\section{Conclusion}

The RM seems to be penetrating virtually every aspect of corporate life, just as the relationships are the essence of life in general. Since human beings are social creatures, they 'be or not to be' is dependent on how well they manage to interact with the others. The companies as social constructs are subjects of the same law. Therefore proposed RM framework interprets the RBV in search for competitive advantage based on relationship assets. It focuses not only on customers, but also on other stakeholders, especially the employees and integrates HRM, KM and CSR as vital parts of employee-related management. Finally it distinguishes three dimensions of relationship approach: the strategy, which defines the overall business model, the ICT as technological strategy enabler and the change management as organizational strategy enabler.

Although this framework may still be supplemented, it constitutes a good bridgehead in developing a grand theory of relationship management. It can also be expanded into an applicable mid-range theory connecting business practice with normative guidelines in form of maturity models fitted with check-lists and defining RM proficiency levels. 


\section{References}

Amann, W., \& Stachowicz-Stanusch, A. (2013). Integrity in organizations, building the foundations of humanistic management. Houndmills: Palgrave Macmillan.

Barney, J. (1991). Firm resources and sustained competitive advantage. Journal of Management, 17(1). doi:10.1177/014920639101700108.

Buttle, F. (2009). Customer relationship management: concepts and technologies. Abingdon: Routledge.

CM FrameWorks. (2017). CMAT. Retrieved 28.03.2017 from http://www.cmframeworks.com.

Deng, H. (2010). A conceptual framework for effective knowledge management using information and communication technologies. International Journal of Knowledge and Systems Science, 1(2). doi:10.4018/jkss.2010040105.

Deszczyński, B. (2013). Lead management jako źródło short-term wins w procesie zarządzania relacjami z klientami. Marketing i Rynek, 5.

Deszczyński, B. (2014). Zasoby relacyjne — konceptualizacja pojęcia w świetle zasobowej teorii przedsiębiorstwa. Studia Oeconomica Posnaniensia, 2(11).

Deszczyński, B. (2016a). The maturity of corporate relationship management. Gospodarka Narodowa, 3(283).

Deszczyński, B. (2016b). Upodmiotowienie pracowników jako element przewagi konkurencyjnej w organizacjach ukierunkowanych na zarządzanie relacjami. Studia Ekonomiczne. Zeszyty naukowe Uniwersytetu Ekonomicznego w Katowicach, 255.

Deszczyński, B., \& Fonfara, K. (2014). Marketing partnerski (relationship marketing) na rynku międzynarodowym. In K. Fonfara (Ed.), Marketing międzynarodowy. Wspótczesne trendy i praktyka. Warszawa: PWN.

Deszczyński, B., Fonfara, K., \& Dymitrowski, A. (2017). The role of relationships in initiating the internationalization process in B2B markets. Entrepreneurial Business and Economics Review, 5(4). doi:10.15678/EBER.2017.050404.

Doney, P.M. \& Cannon, J.P. (1997). An examination of trust in buyer-seller relationships. Journal of Marketing, 61(2). doi:10.2307/1251829.

Doyle, P. (2003). Marketing wartości. Warszawa: Felberg SJA.

Drucker, P.F. (2010). Classic Drucker. Warszawa: MT Biznes.

Galbreath, J., \& Rogers, T. (1999). Customer relationship leadership: a leadership and motivation model for the twenty-first century business. The TQM Magazine, 11(3). doi:10.1108/09544789910262734.

Gummesson, E. (1999). Total relationship marketing: experimenting with a synthesis of research frontiers. Australasian Marketing Journal, 7(1). doi:10.1016/ S1441-3582(99)70204-1.

Gummesson, E. (2008). Marketing is managing relationships, networks and interaction. Speech given at EASM Heidelberg September 2008. 
Gummesson E. (2014). Productivity, quality and relationship marketing in service operations. A revisit in a new service paradigm. International Journal of Contemporary Hospitality Management, 26(5). doi:10.1108/ IJCHM-01-2014-0017.

Gummesson, E. (2017a). From relationship marketing to total relationship marketing and beyond. Journal of Services Marketing, 31(1). doi:10.1108/ JSM-11-2016-0398.

Gummesson, E. (2017b). Total relationship marketing renewed. Abingdon: Routledge.

Gordon, I.H. (2013). Managing the new customer relationship, strategies to engage the social customer and build lasting value. New York: J. Wiley \& Sons.

Grönroos, Ch. (2007). The CSS model, developing service offerings based on service's inherent sources of competitive advantage. In M.H.J. Gouthier, Ch. Coenen, H.S. Schulze \& Ch. Wegmann (Eds.), Service Excellence als Impulsgeber. Wiesbaden: Gabler.

Grönroos, Ch. (2011). Value co-creation in service logic: a critical analysis. Marketing Theory, 11(3). doi:10.1177/1470593111408177.

Grönroos, Ch., \& Strandvik, T. (2008). The interaction concept and its implications for value creation and marketing in service businesses. In M. Antilla \& M. Rajala (Eds.), Fishing with business nets - keeping thoughts on the horizon Professor Christian Möller. Helsinki: Helsinki Kauppakorkeakoulu.

Hamel, G. (2002). Leading the revolution. Harvard: Harvard Business School Press.

Hamel, G., \& Prahalad, C.K. (1999). Przewaga konkurencyjna jutra: Strategie przejmowania kontroli nad branżą i tworzenia rynków przysztości. Warszawa: Business Press.

Injazz, J. \& Popovich, K. (2003). Understanding customer relationship management (CRM). Business Process Management Journal, 9(5). doi:10.1108/14637150310496758.

Jones, T.O. \& Sasser, W.E. Jr. (1995). Why satisfied customers defect. Harvard Business Review, November-December.

Kotter, J.P., \& Heskett, J.L.. (1992). Corporate culture and performance. New York: Free Press.

Mitręga, M. (2012). Network partner knowledge and internal relationships influencing customer relationship quality and company performance. Journal of Business \& Industrial Marketing, 27(6). doi:10.1108/08858621211251488.

Mitręga, M. (2015). Bariery wdrożenia marketing relacji w polskich przedsiębiorstwach. Studia Ekonomiczne. Zeszyty naukowe Uniwersytetu Ekonomicznego w Katowicach, 233.

Mitręga, M., Forkmann, S., Ramos, C., \& Henneberg, S.C. (2012). Networking capability in business relationships - Concept and scale development. Industrial Marketing Management, 41(5). doi:10.1016/j.indmarman.2012.06.002. 
Nonaka, I. \& Peltokorpi, V. (2006). Objectivity and subjectivity in knowledge management: a review of 20 top Articles. Knowledge and Process Management, 13(2). doi:10.1002/kpm.251.

O’Riordan, L., Zmuda, P. \& Heinemann, S. (2015). New perspectives on corporate social responsibility, locating the Missing Link. Wiesbaden: Springer Fachmedien.

Otto, J. (2001). Marketing relacji. Koncepcja i stosowanie. Warszawa: C.H. Beck.

Otto. J. (2004). Zarządzanie wartością klienta marketingowym wymogiem konkurencyjności współczesnego przedsiębiorstwa - wybrane problemy. Acta Universitatis Lodziensis Folia Oeconomica, 179.

Payne, A., Frow, P. (2013). Strategic customer management, integrating relationship marketing and CRM. Cambridge: Cambridge University Press.

Peck, H., Christopher, M., Clark, M. \& Payne, A. (2013). Relationship marketing. Abingdon: Taylor \& Francis.

Peppers, D. \& Rogers, M. (2004). Managing Customer Relationships: A Strategic Framework. New York: Wiley.

Peppers, D., \& Rogers, M. (2011). Managing customer relationships: a strategic framework. New York: Wiley. doi:10.1002/9781118371510.part2.

Peppers D., Rogers M., \& Dorf B. (1999). Is your company ready for one-toone marketing? Harvard Business Review, January-February.

Piercy, N. (2003). Marketing. Strategiczna reorientacja firmy. Warszawa: Felberg. Reichheld, F.F., \& Markey, R., (2013). The economics of loyalty. Retrieved 10.02.2016 from http://www.bain.com.

Sasser, W.E., Schlesinger, L.A., \& Heskett, J.L. (1997). Service profit chain. New York: Simon and Schuster.

Smith, J. (2006). Empowerment. Jak zwiększyć zaangażowanie pracowników. Gliwice: Helion.

Srivastava, M. (2013). Principles of Managing Customer Relationships. Samvad, 16.

Stachowicz-Stanusch, A. \& Stanusch, M. (2007). CRM. Przewodnik dla wdrażających. Warszawa: Placet.

Starkey, M., Williams, D., \& Stone, M. (2002). The state of customer management performance in Malaysia. Marketing Intelligence \& Planning, 20(6). doi:10.1108/02634500210445437.

Szymura-Tyc, M. (2003). Wartość dla klienta jako źródło przewagi konkurencyjnej. Organizacja i Kierowanie, 4.

Szymura-Tyc, M. (2004). Marketing we współczesnych procesach tworzenia I dostarczania wartości klientom. Acta Universitatis Lodziensis Folia Oeconomica, 179.

Tvede, L., \& Ohnemus, P. (2001). Marketing strategies for the new economy. New York: J. Wiley \& Sons.

Vargo, S.L., \& Lusch, R.F. (2016). Service-dominant logic: continuing the evolution. Journal of the Academy of Marketing Science, 36(1). doi:10.1007/ sll747-007-0069-6. 
Wagner, S.M., \& Johnson, J.L. (2004). Configuring and managing strategic supplier portfolios. Industrial Marketing Management, 33(8). doi:10.1016/j. indmarman.2004.01.005.

Zdziarski, M. (2016). Nurt sieciowy - w kierunku nowego paradygmatu zarządzania? Prace Naukowe Uniwersytetu Ekonomicznego we Wroctawiu, 421. doi:10.15611/pn.2016.421.52.

\section{Acknowledgements}

Author contributions: author has given an approval to the final version of the article.

Funding: this research was undertaken as part of the project (2015/19/D/HS4/01956) and was fully funded by the Polish National Science Centre.

Note: the results of this study were presented at 9th International Conference on Applied Economics Contemporary Issues in Economy (June 22-23, Torun, Poland). 


\section{Appendix}

Scheme 1 .

The integrated relationship management framework
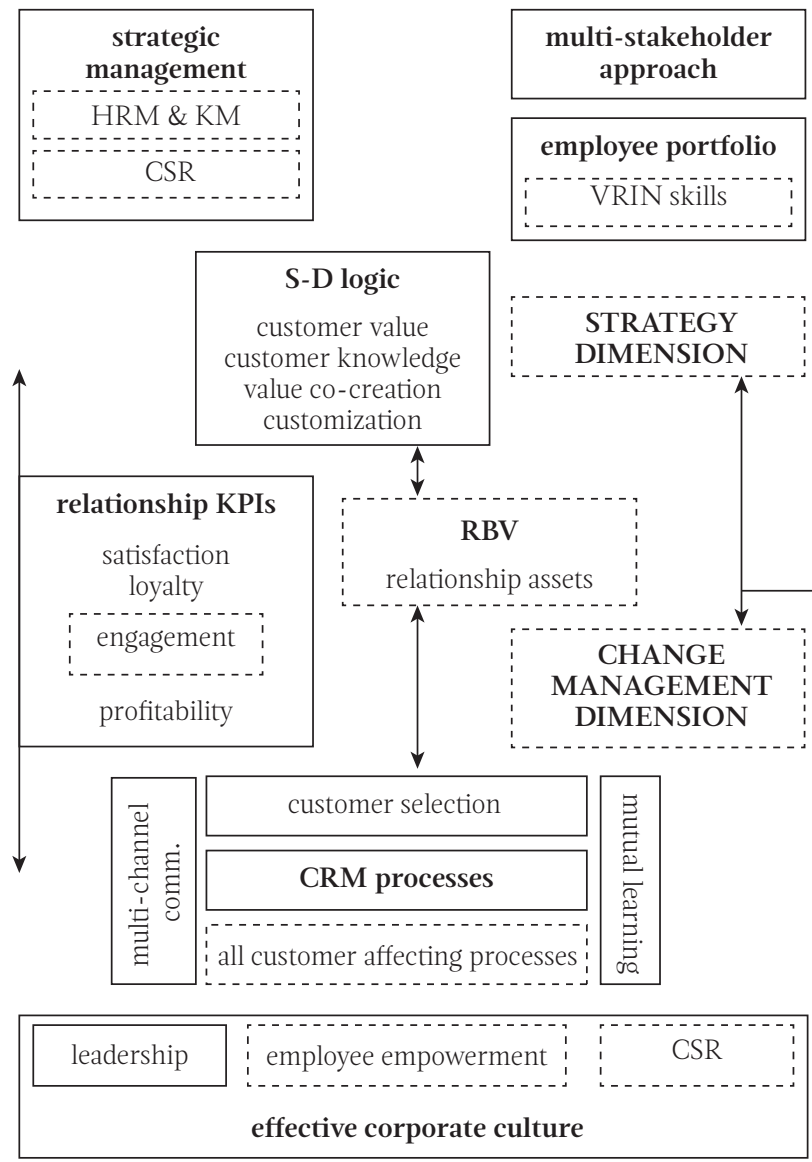

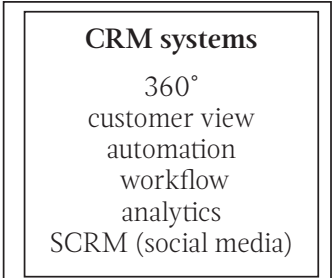

\section{ICT governance}

structural embeddedment business goals delivery

ICT DIMENSION

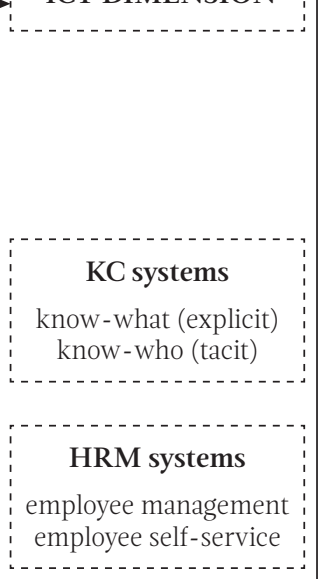

Source: Own preparation. 
